\title{
Plant community structure and possible vegetation changes after drought on a granite catena in the Kruger National Park, South Africa
}

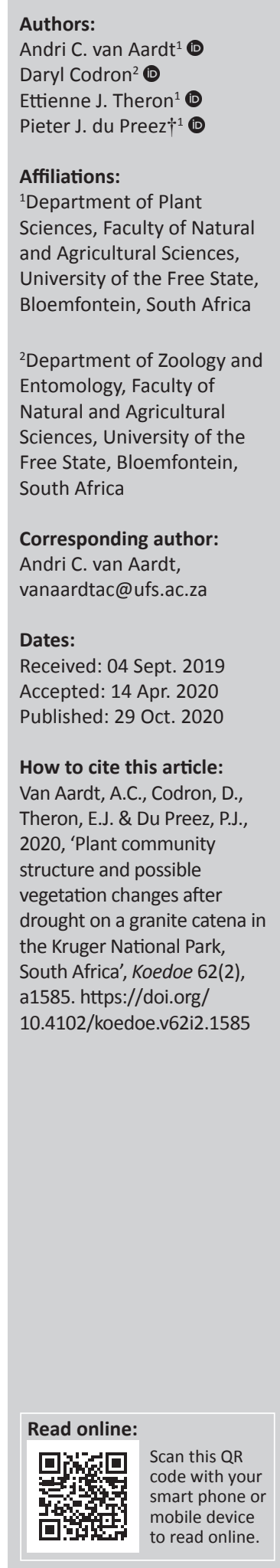

A preliminary study investigated the associations between vegetation communities along catenary soil gradients in 2015. The severe drought of 2016 in South Africa presented the opportunity to study post-drought savanna vegetation changes. This hillslope transect was surveyed for five successive seasons. The Braun-Blanquet method was used, and the data were analysed by means of the TWINSPAN algorithm, which resulted in the classification of different communities on the crest, sodic site and riparian area. Change in herbaceous and grassy vegetation composition and diversity in the transect is compared between rainfall years, wet and dry seasons, and three different zones (crest, sodic site and riparian areas). Spatial and temporal autocorrelation of the woody component shifted the focus to variance within the graminoid and herbaceous layers. Clear vegetation changes were observed on the crest and the sodic sites, whereas changes in the riparian area were less obvious. In all three habitats, species richness decreased after the drought and did not reach pre-drought levels even after two years. However, plant species diversity was maintained as climax species were replaced by pioneer and sub-climax species. These changes in community structure, which had reverted to systems dominated by climax species by the end of the sampling period, might be an indication of the savanna ecosystem's resilience to drought conditions.

Conservation implications: Although clear vegetation changes were observed in the five successive seasons after the drought, this study showed that the savanna ecosystem is relatively resistant to drought and that human intervention is not needed.

Keywords: Drought; Vegetation classification; Savanna; Diversity; Catena.

\section{Introduction}

The Earth's environment is dominated by three great natural components, namely, climate, vegetation and soil. Climate is considered the most important factor influencing the distribution and composition of vegetation on a micro and sub-continental scale (Campbell et al. 2008; Furley 2010; Scholes 1997; Schulze 1997). Vegetation development is controlled largely by light, temperature and moisture (Bond, Midgley \& Woorward 2003; Schulze 1997). Topography and the chemical and physical compositions of the soil also influence vegetation and, in conjunction with climate, are responsible for the intricate interactions that govern the worldwide distribution of vegetation (Campbell et al. 2008; Furley 2010; Scholes 1997). Understanding how these interactions regulate the ecology of plant communities is critical for characterising the impacts of global change on biodiversity at local and regional scales.

The savanna biome is unique because it consists of both woody vegetation and a grass layer. Climate and other regulating factors likely affect these two components differently, resulting in spatio-temporal heterogeneity of tree:grass compositions. Severe droughts, for example, may remove trees, leading to negative effects on woody plant diversity (Swemmer 2016; Walker et al. 1987; Zambatis \& Biggs 1995). By reducing tree densities, droughts in savanna provide opportunities for drought-adapted flora to thrive, for instance, by promoting seedling recruitment of fast-growing, palatable shrub species and the re-establishment of a grassy layer (Swemmer et al. 2018; Vetter 2009). In this way, drought can help maintain the balance between trees and grasses (Swemmer 2016). Grasses, on the other hand, can take decades to recover their

Copyright: @ 2020. The Authors. Licensee: AOSIS. This work is licensed under the Creative Commons Attribution License.

Note: Additional supporting information may be found in the online version of this article. Online Appendix 1; Online Appendix 2; and Online Appendix 3.

Note: Special Issue: Connections between abiotic and biotic components of a granite catena ecosystem in Kruger National Park, sub-edited by Beanelri Janecke and Johan van Tol.

$\dagger, 1960-2019$. 
productive potential or might recover comfortably before the next drought (Swemmer et al. 2018). The herbaceous layer thus also regularly experiences negative responses to drought (Zambatis \& Biggs 1995); however, Abbas, Bond and Midgley (2019) indicated that grasses can resprout vigorously after the onset of rainfall events. In fact, this layer usually responds to droughts and other climate changes first, primarily because of the shallow depth of root penetration. Upper soil layers are more susceptible to desiccation than the deeper strata penetrated by many woody plants. Furthermore, the extensive root structures of trees increase their access to subterranean reserves of ground water. Shorter term responses of grassy and herbaceous vegetation were highlighted by Buitenwerf, Swemmer and Peel (2011), who showed that dynamics of this savanna component are mainly controlled by interannual changes in rainfall. The response of the grass layer to climate is of importance for conservation planning and application, because it is an important food source for grazer populations (Staver, Wigley-Coetzee \& Botha 2018).

The savanna regions of South Africa are considered semiarid, receiving rainfall mostly during the summer months between October and April (Walker et al. 1987). Fluctuations in annual rainfall, including droughts, are a regular and recurrent feature of the climate (Rouault \& Richard 2003). In more than half of the 80 summer rainfall districts identified by Rouault and Richard (2003), droughts were recorded during 1926, 1933, 1945, 1949, 1952 1970, 1983 and 1992 (Fauchereau et al. 2003; Rouault \& Richard 2003; Gommes \& Petrassi 1996). Rouault and Richard (2003) and Staver et al. (2018) indicated that the 1982-1983 drought was the worst drought recorded since 1922; however, Swemmer (2016) indicated that the drought of 2015-2016 was the worst drought that the Lowveld experienced in the past 33 years. In the savanna areas of KwaZulu-Natal, this drought was shown to be the worst in 50 years by Abbas et al. (2019). Research by Hu and Fedorov (2019) indicated that the drought of 2015-2016 was worse than the droughts of 1982 and 1997. These studies show that, since the 1960s, drought is more often associated with El Niño events; notably, however, annual rainfall during wet years has also increased since the 1970s.

South African savannas experienced drought conditions during the rainfall seasons of 2014-2015 and 2015-2016. In the Kruger National Park (KNP), and the surrounding areas of the Lowveld, below average rainfall occurred at annual (255 mm) and monthly scales (Swemmer 2016). This resulted in devastating effects on vegetation, animal and human welfare in certain areas. These years were also marked by unusually high temperatures, resulting in higher evaporation rates, further reducing water availability (Swemmer 2016). The severity of these conditions provided us with the opportunity to study their effects on short-term responses of vegetation, specifically on the grassy and herbaceous component. We conducted a study of seasonal and annual plant community dynamics along a granitic catenal gradient. This catena forms part of a research supersite, where long-term research is needed to establish baselines for monitoring and understanding ecological change (Smit et al. 2013). We describe taxonomic community changes, as well as testing for shifts in diversity, over two wet and two dry seasons through the drought period and compare these with pre-drought conditions (April 2015) described elsewhere (Theron, Van Aardt \& Du Preez 2020). We focused only on the herbaceous and grassy components of the vegetation because we were interested in resolving short-term responses in savanna plant resilience to drought.

\section{Study area}

The study site is in the southern parts of KNP south of Skukuza (see study area figure in Theron et al. 2020) at $25.111^{\circ} \mathrm{S}$ and $31.579^{\circ} \mathrm{E}$. Kruger National Park falls within the arid 'BSh' (hot semi-arid climate) climate type according to the Köppen-Geiger classification system (Venter, Scholes \& Eckhardt 2003). 'BSh' is one of the four climate types within this category. The main features of 'BSh' climate are distinct seasonal rainfall and temperature variations. Mean annual precipitation in KNP is generally in the range of $650 \mathrm{~mm}$ annually (Smit et al. 2013). On a local scale, MAP of the Granite Lowveld varies between 450 and $900 \mathrm{~mm}$ along the eastern plains and the western escarpment, respectively (eds. Mucina \& Rutherford 2006). However, the average annual total rainfall as recorded at the Skukuza Meteorological Station is $553 \mathrm{~mm}$ (Zambatis 2006). The mean annual temperature in the vicinity of the study area varies between $21^{\circ} \mathrm{C}$ and $22^{\circ} \mathrm{C}$ (Khomo et al. 2011; Scholes, Bond \& Eckhardt 2003). This area experiences an insignificant seasonal and diurnal temperature variation with extreme periods of inundation and aridity (Kruger, Makamo \& Shongwe 2002). The study site is underlain by the Nelspruit Suite geological formation and consists of granite and gneiss mostly occurring in the eastern parts of KNP (Alard 2009; Smit et al. 2013; Van Zijl \& Le Roux 2014). Granite gneiss is widespread in the eastern regions of KNP and results in shallow, nutrient-poor soils that vary from grey to red to brown in colour (Venter 1990). Descriptions of the different soil forms found along the catena at the site were provided in Figure 2 within the article by Theron et al. (2020). The vegetation type at the study site is mostly Granite Lowveld (SVI3), characterised by a ground layer of tall grasses with

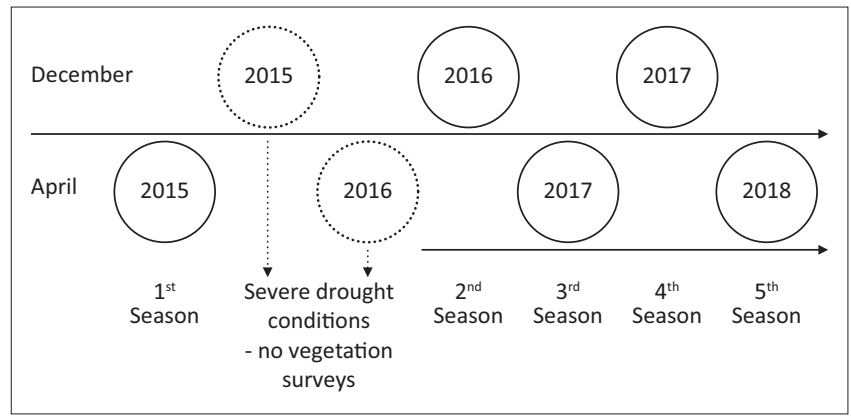

FIGURE 1: Survey events timeline: First season represented by April 2015; December 2015 and April 2016 no sampling because of lack of vegetation; second season represented by December 2016; third season represented by April 2017; fourth season represented by December 2017; and fifth season represented by April 2018. 
intermittent trees and other woody species (eds. Mucina \& Rutherford 2006).

\section{Methods \\ Data collection}

The same hillslope transect was surveyed for five seasons; the first survey was conducted prior to the onset of severe drought conditions (Theron et al. 2020) during December 2015 and April 2016 (Figure 1). The second and fourth surveys represent the start of the rainy summer season, while the third and fifth surveys reflect the end thereof (Figure 1). Relevés of $10 \mathrm{~m}^{2}$ were aligned along a $500 \mathrm{~m}$ transect. Cover abundance was recorded per species according to the modified Braun-Blanquet scale (Kent 2012; Kent \& Coker 1992; Van der Maarel \& Franklin 2013; Theron et al. 2020).

\section{Classification, richness and diversity analysis}

The analysis done by Theron et al. (2020) indicated that the catenal vegetation communities can be divided into crest, sodic site and riparian areas. Each of these habitat types contains different plant communities that are bound by different soil forms. Thus, the analysis of data for the seasons after the drought (December 2016-April 2018) was guided by these differentiations. Each topographical unit was thus analysed separately to look at the vegetation composition or change over the period of December 2016-April 2018. During this study, December samples were regarded as wet seasons, and April samples were regarded as dry seasons, irrespective of the delayed effect, because most summer rainfall usually occurred during December.

\section{Classification}

VegCap (unpublished database tool designed by N. Collins) was used to capture vegetation data into a macro-enabled Excel spreadsheet. From there, the data were imported into JUICE@ (Tichý \& Holt 2006) where a Modified TWINSPAN Classification (Roleček et al. 2009) analysis was carried out. Parameters for this analysis included the following: pseudospecies cut level (5); analysis was constrained to a minimum group size of 3-54 clusters; and division reached an endpoint if dissimilarity went lower than 0.3 based on average Sorensen dissimilarity. The resulting clusters were then arranged within both JUICEC and Excel to form the final vegetation communities. Although all the species were recorded during the field surveys, woody species were removed from the data in order to look at the change in graminoids and herbaceous species after the drought. This follows, for example, Rouault and Richard (2003), who indicated that trees and other vegetation with extensive root structures have access to subterranean reserves of groundwater and will thus not be immediately affected by the drought. The naming of communities and subcommunities was carried out according to the guidelines presented in Brown et al. (2013). In order to obtain diagnostic, constant and dominant species, we made use of the Analysis of Columns of a Synoptic Table in JUICE. The frequency thresholds were set at 75, 60 and 50 for the respective diagnostic, constant and dominant species. An asterisk indicates alien invasive species.

\section{Diversity and richness}

In addition to descriptions of community composition and how this changed over time, we evaluated changes in diversity and compared these across time for each of the three communities. We compared changes in species richness as well as changes in alpha-diversity. We used the Chao estimator as an indicator of species richness, as this index accounts for the occurrences of singletons and doubletons, and the Shannon index was used to quantify alpha-diversity. For each sample (i.e. per season and per habitat), ordinal abundance data as scored by the Braun-Blanquet system were converted to abundance cover data, rounded to integer values, following Van der Maarel (2007): $r=1 ;+=2 ; 1=3$; $2 \mathrm{a}=8 ; 2 \mathrm{~b}=18 ; 3=38 ; 4=63 ; 5=88$. Diversity estimates were computed using the iNext package (Hsieh, Ma \& Chao 2016) for R (R Core Team 2015). The iNext function was used for extrapolation and prediction of diversity indices based on rarefaction procedures, with the expected means and standard errors extrapolated from the asymptotes of the fitted accumulation curves (see Figure 2). In all cases, accumulation curves approached or reached an asymptote, and observed data represented between 80 and 100\% of extrapolated estimates (in the case of species richness), and between $94 \%$ and $100 \%$ of extrapolated estimates (for Shannon diversity), depending on the sample. Thus, sampling effort is considered sufficient for reliable estimations of diversity in these communities.

\section{Ethical considerations}

Ethical approval was obtained from the Interfaculty Animal Ethics Committee of the University of the Free State (UFSAED2019/0121).

\section{Results and discussion Classification}

Different plant communities were classified for each topographical unit as defined by Theron et al. (2020). In this article, the data for 2015 were not included in the classification in order to prevent a repetition of information.

\section{Crest communities (December 2016-April 2018)}

These communities located on the crest zone and upslope beyond the sodic site occur on the Clovelly, Pinedene, Fernwood, Estcourt, Mispha and Sterkspruit soil forms (Theron et al. 2020). The soil depth varies from 533 to $620 \mathrm{~mm}$ deep, with an average $\mathrm{pH}_{\mathrm{H}_{2} \mathrm{O}}$ of 5.95-6.08. Soil texture is mostly loamy sand to coarse loamy sand (Theron et al. 2020). Vegetation classification resulted in three communities and two sub-communities that perfectly align with the different sampling seasons, showing a clear change in vegetation composition since the onset of the rainy season in December 2016 (Online Appendix 1). Although there are only 

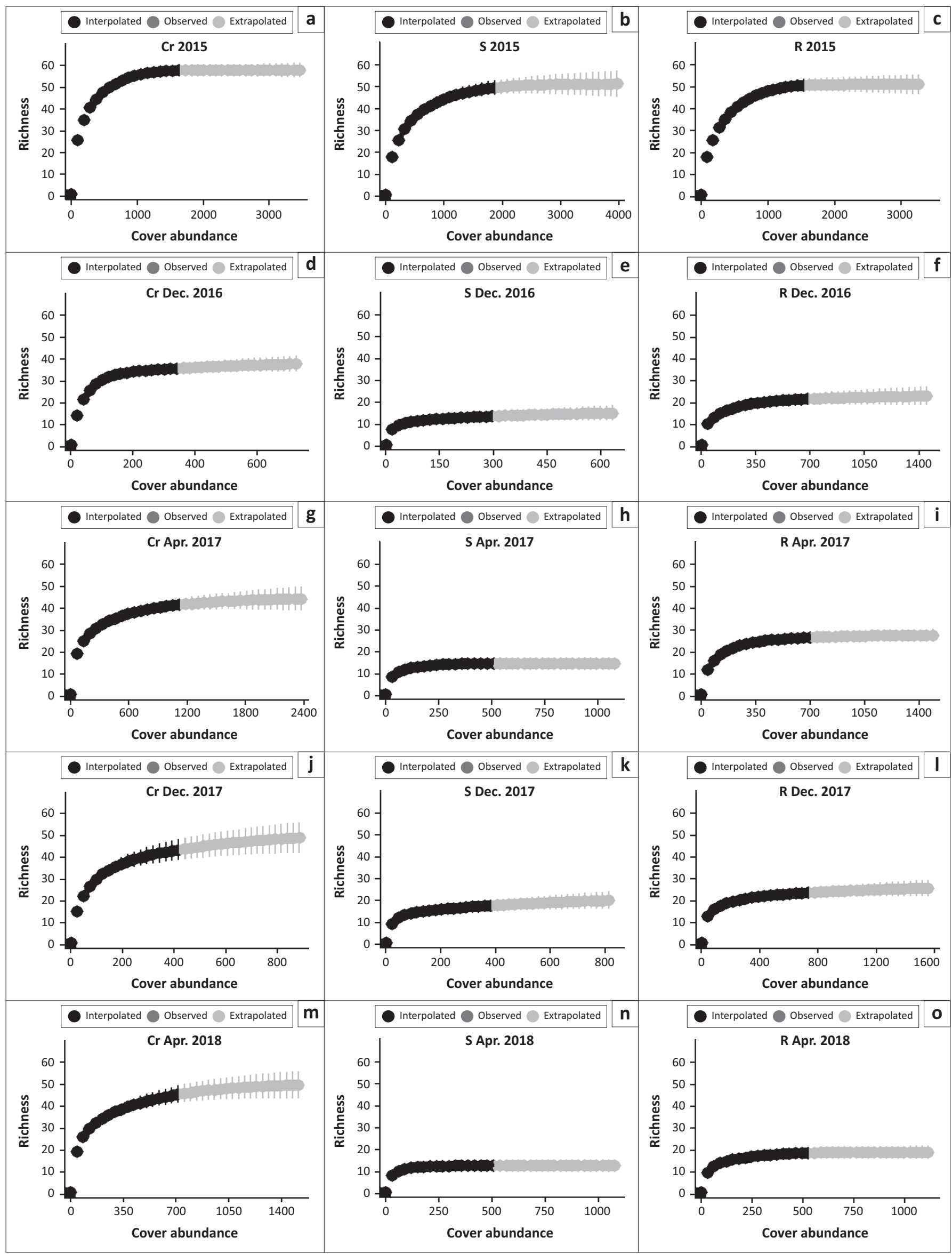

FIGURE 2: Rarefied species accumulation curves for herbaceous vegetation from the three habitats $(\mathrm{Cr}=\mathrm{crest}, \mathrm{S}=\mathrm{sodic}, \mathrm{R}=\mathrm{riparian})$ sampled at five time intervals from a single catenal transect ( $10 \mathrm{~m}^{2}$ neighbouring relevés forming $500 \mathrm{~m}$ long belt transect) in the southern KNP. Error bars depict $95 \%$ confidence intervals of the richness estimates. 
three communities, the sub-communities of community 3 distinguish between season 4 (S4) (December 2017) and season 5 (S5) (April 2018), although their composition was very similar. The vegetation of the crest communities can be compared to community 3 (Vachellia excuvialis-Pogonarthria squarrosa) from Theron et al. (2020). As indicated in the 'Materials and methods' section, data on the woody species were removed as it obscured the focus of this study:

1. Heliotropium ciliatum-Cleome monophylla Community

2. Zorniaglochidiata-Crotalaria sphaerocarpa subsp. sphaerocarpa Community

3. Aristida congesta subsp. barbicollis-Bulbostylis *barbata Community

3.1. Aristida congesta subsp. barbicollis-Bulbostylis *barbataMelhania acuminata Sub-community

3.2. Aristida congesta subsp. barbicollis-Bulbostylis *barbataSchmidtia pappophoroides Sub-community

Crest community descriptions:

\section{Heliotropium ciliatum - Cleome monophylla Community}

Diagnostic species: Cleome monophylla 84.3, Heliotropium ciliatum 93.4

Constant species: Bare soil 77, Bulbostylis hispidula 77, Chlorophytum recurvifolium 62, Cleome monophylla 92, Dipcadi papillatum 62, Heliotropium ciliatum 100, Kyllinga alba 85, Phyllanthus maderaspatensis 62, Tragus berteronianus 77, Urochloa mosambicensis 85

Dominant species: None

This community mostly represents vegetation sampled during the December 2016 (S2) season. Species from Species Group A (Online Appendix 1) define this community. These species are mostly absent or occur with very low coverabundance values in the other communities. From a growthform perspective, it is notable that this community contains the most geophytic plants. There is also a strong presence of species from Species Group B and Species Group I and the 'pseudo-species' indicated as bare soil (Species Group J):

2. Zorniaglochidiata-Crotalaria sphaerocarpa subsp. sphaerocarpa Community

Diagnostic species: Crotalaria sphaerocarpa s. sphaerocarpa 82.3, Zornia glochidiata 84.8

Constant species: Aristida congesta s. congesta 79, Crotalaria sphaerocarpa s. sphaerocarpa 74, Eragrostis superba 63, Pogonarthria squarrosa 95, Setaria sphacelata v. sericea 63, Tricholaena monachne 68, Vernonia fastigiata 79, Zornia glochidiata 89

Dominant species: None

Vegetation found in this community represents the sampling during April 2017, which is mostly dominated by species from Species Group C (Online Appendix 1). Again, the species found here do not occur in other communities. Notable is the high cover abundance of species found in this community when compared to that of community 1. Furthermore, species from Species Group B are shared between community 1 and community 2; however, Aristida congesta subsp. congesta occur with much higher cover abundance in community 2 than in community 3. A possible explanation for that might be the increase in rainfall after the severe drought experienced in 2015-2016. From Species Group H, it is also clear that the grasses Eragrostis cylindriflora, Aristida adscensionis and Melinis repens start to establish with average cover-abundance values:

3. Aristida congesta subsp. barbicollis-Bulbostylis *barbata Community

Diagnostic species: Aristida congesta s. barbicollis 77.1, Bulbostylis barbata 79.4

Constant species: Aristida congesta s. barbicollis 75, Bare soil 81, Bulbostylis barbata 78, Schmidtia pappophoroides 66

Dominant species: None

This community represents sampling seasons 4 and 5 (December 2017 and April 2018), which is more or less one year after rainfall occurred that terminated the 2015-2016 drought. Species from Species Group F distinguishes this community from the other communities. Plants from Species Group $\mathrm{H}$ also started to occur in more relevés during these seasons, which might indicate that the veld was starting to improve after the drought conditions:

3.1. Aristida congesta subsp. barbicollis-Bulbostylis *barbataMelhania acuminata Sub-community

\section{Diagnostic species: Melhania acuminata 79.4, Panicum coloratum 78.5}

Constant species: Aristida congesta s. barbicollis 94, Bare soil 100, Bulbostylis barbata 81, Eragrostis cylindriflora 69, Hibiscus micranthus v. micranthus 62, Melhania acuminata 88, Panicum coloratum 75, Panicum maximum 69, Perotis patens 88, Pogonarthria squarrosa 94, Tricholaena monachne 75

Dominant species: None

Sub-community 3.1 mostly represents vegetation sampled during April 2018 (S5). This sub-community is distinguished by the presence of species from Species Group E, which are either absent from other communities or occur with very low cover-abundance values. When looking at Species Group D, it is clear that the graminoids (Pogonarthria squarrosa, Tricholaena monachne, Eragrostis superba and Digitaria eriantha) mostly occur during the December sampling seasons (S3 and S5). Although these grasses do occur in other communities, it is with very low cover abundance:

3.2. Aristida congesta subsp. barbicollis-Bulbostylis *barbataSchmidtia pappophoroides Sub-community

Diagnostic species: None

Constant species: Aristida adscensionis 62, Bare soil 62, Bulbostylis barbata 75, Schmidtia pappophoroides 75, Urochloa panicoides 62

Dominant species: None

This sub-community represents crest vegetation during April 2017 (S4). Species Group G distinguishes this subcommunity from the Aristida congesta subsp. barbicollisBulbostylis *barbata-Melhania acuminate sub-community 3.1. Furthermore, the absence of species from Species Group E is also very prominent in this sub-community. However, from Species Group F it is clear that the cover-abundance 
values of Aristida congesta subsp. barbicollis and Panicum maximum decreased from sub-community 3.1 to 3.2. A possible explanation might be that during December 2017 (S4; sub-community 3.2), the species only started to establish at the site and favourable environmental conditions such as an increase in rainfall allowed the improvement of cover in April 2018 (S5; sub-community 3.1).

The above community descriptions cannot be directly compared to what was found in 2015 (Theron et al. 2020) because of the removal of the woody species which then dominated the community. There are, however, species such as Aristida congesta, Tricholaena monachne, Melhania acuminata, Panicum maximum and Perotis patens that occur on the site during most of the sampling seasons. It is, nevertheless, clear that the grass Pogonarthria squarrosa (Species Group D) only started to reappear in the vegetation in growing season 3 (April 2017), then diminished and reappeared again in growing season 5 (April 2018). This might indicate that this grass is also restricted to certain sampling seasons and does not occur on the crest sites throughout the year. Van Oudtshoorn (2018) indicated that P. squarrosa is a weak perennial tufted grass that can grow for two to five seasons. Diminishing of this grass during season 4 (December 2017) might therefore still be due to the effects of the drought; indicating that the droughtstill affected vegetation composition one year after the onset of the rainy season.

\section{Sodic site communities (December 2016-April 2018)}

The communities occur between the crest and the riparian area on the mid-slope of the hill, and are also sodic sites. Soils are mostly of the Sterkspruit form; however, there were also instances of Mispah soil forms present. The depth varies between $180 \mathrm{~mm}$ and $500 \mathrm{~mm}$ with an average $\mathrm{pH}_{\mathrm{H} 2 \mathrm{O}}$ of $6.20-6.43$. Soil texture is coarse sandy loam. The vegetation classification resulted in two communities and four sub-communities (Online Appendix 2). In terms of vegetation composition, these communities can be compared to the Dactyloctenium aegyptium-Sporobolus nitens (community 4) of Theron et al. (2020):

1. Tribulus terrestris-Portulaca *oleracea Community

a. Tribulus terrestris-Portulaca *oleracea-Urochloa panicoides Sub-community

b. Tribulusterrestris-Portulaca*oleracea-Heliotropium ciliatum Sub-community

2. Chloris virgata-Eragrostis cylindriflora Community

a. Chloris virgata-Eragrostis cylindriflora-Sporobolus nitens Sub-community

b. Chloris virgata-Eragrostis cylindriflora-Chloris gayana Sub-community

Sodic site community descriptions:

\section{Tribulus terrestris-Portulaca *oleracea Community}

Diagnostic species: Portulaca oleracea 78.5, Tribulus terrestris 89.8

Constant species: Bare soil 96, Cynodon dactylon 64, Portulaca *oleracea 86, Schkuhria pinnata 100, Tribulus terrestris 89, Urochloa mosambicensis 68

Dominant species: None
This community is defined by species from Species Group C, which occur here and are absent from other communities or occur with low cover-abundance values. Cynodon dactylon is known as a pioneer grass (Van Oudtshoorn 2018) and Tribilus terrestris is known to occur in disturbed areas (Van Wyk \& Malan 1998). Portulaca *oleracea is a creeping succulent that grows vigorously under warm conditions covering the soil surface (Bromilow 2018). This community was mostly restricted to April 2017 (S2) and April 2018 (S4). Thus, again as seen in the Crest communities, there are certain species that show preferences for certain sampling seasons:

1.1. Tribulus terrestris-Portulaca *oleracea-Urochloa panicoides Sub-community

Diagnostic species: Urochloa panicoides 91.7

Constant species: Alternanthera pungens 62, Bare soil 94, Portulaca oleracea 81, Schkuhria pinnata 100, Sporobolus nitens 69, Tribulus terrestris 81, Urochloa panicoides 88

Dominant species: None

The vegetation found in this sub-community mostly represents species from growing season 4 with a single occurrence of season 2. Species from Species Group A (Online Appendix 2) define this sub-community. These species are completely absent or occur with very low cover-abundance values in other communities and sub-community on the sodic site. Urochloa panicoides, which defines this sub-community, is known as a pioneer annual tufted grass and will thus only be present for one season (Van Oudtshoorn 2018). In this subcommunity, this grass co-occurs with Sporobolus nitens, which defined the communities found in 2015 before the drought:

1.2. Tribulusterrestris-Portulaca*oleracea-Heliotropium ciliatum Sub-community

Diagnostic species: None

Constant species: Bare soil 100, Cynodon dactylon 75, Gomphrena celosioides 67, Heliotropium ciliatum 92, Ledebouria luteola 67, Portulaca oleracea 92, Schkuhria pinnata 100, Tribulus terrestris 100, Urochloa mosambicensis 92

Dominant species: None

This sub-community is mostly represented by growing season 2 (December 2016) at the onset of the rainy season after the severe drought. Furthermore, this sub-community is defined by the presence of species from Species Group B, which include two geophytic species. There is also a complete absence of the species from Species Group A in this subcommunity. Very notable in this sub-community is the almost complete absence of Sporobolus nitens (Species Group G) and Dactyloctenium aegyptium (Species Group F), which completely dominated the vegetation during 2015 (growing season 1) (Theron et al. 2020):

2. Chloris virgata-Eragrostis cylindriflora Community

Diagnostic species: Chloris virgata 83.5

Constant species: Alternanthera pungens 78, Bare soil 85, Chloris virgata 100, Dactyloctenium aegyptium 67, Eragrostis cylindriflora 74, Schkuhria pinnata 96, Sporobolus nitens 93, Urochloa mosambicensis 70

Dominant species: Bare soil 4 
This community is defined by the presence of species from Species Group F. Although some of the species that occur in this Species Group were also present in community 1, they occur with much higher cover-abundance values in community 2 :

2.1. Chloris virgata-Eragrostis cylindriflora-Sporobolus nitens Sub-community

Diagnostic species: None

Constant species: Alternanthera pungens 92, Bare soil 100, Chloris virgata 100, Dactyloctenium aegyptium 62, Gomphrena celosioides 92, Schkuhria pinnata 92, Sporobolus nitens 100, Urochloa mosambicensis 92

Dominant species: None

Vegetation in this sub-community is mostly from growing season 5 (April 2018) with a single occurrence of vegetation from growing season 3 (April 2017). Although S. nitens is the diagnostic species for this sub-community, the presence of species from Species Group D defines this sub-community. These species are completely absent from sub-community 2.2. Season 5 marks the return of S. nitens (with high cover abundance) and Dactyloctenium aegyptium (with low cover-abundance and only in some relevés) which dominated the communities found on the sodic site by Theron et al. (2020) in 2015:

2.2. Chloris virgata-Eragrostis cylindriflora-Chloris gayana Sub-community

Diagnostic species: None

Constant species: Alternanthera pungens 64, Bare soil 71, Chloris gayana 71, Chloris virgata 100, Dactyloctenium aegyptium 71, Eragrostis cylindriflora 93, Schkuhria pinnata 100, Sporobolus nitens 86

Dominant species: Bare soil 7

Sub-community 2.2 is defined by the presence of perennial grasses from Species Group E, which are absent from subcommunity 2.1. Although having low cover abundances and not occurring in all relevés, this is the only season in which these grass species were found. All three of these grass species (Chloris gayana, Eragrostis gummiflua and Aristida stipitata) are regarded by Van Oudtshoorn (2018) as sub-climax species, which might indicate that after the third season, the sodic site started to recover from the severe drought of 2015-2016.

Species such as Schkuhria pinnata, Urochloa mosambicensis and Chloris virgata occurred on the site through most of the sampling seasons since 2015. Sporobolus nitens that formed part of the diagnostic species that defined the sodic site communities in 2015 (Theron et al. 2020) only started to appear in April 2017 (S3) with low cover-abundance values. The high cover-abundance values of this diagnostic species only started returning in December 2017 (S4) and increased in April 2018 (S5). From Online Appendix 2, it is clear that certain species on the sodic site are restricted to certain sampling seasons such as April or December. However, it is also clear that the vegetation composition on the sodic site changed from December 2016 until April 2018. The mentioned changes can possibly be assigned to the recovery of the site after the drought of 2015-2016.
Riparian area communities (December 2016-April 2018)

The communities occur between the sodic site on the lower midslope of the hill and the drainage line. Soil forms found in this area include Dundee, Mispah, Bonheim and Sterkspruit. The depth of these soils varies from $100 \mathrm{~mm}$ to $600 \mathrm{~mm}$ with an average $\mathrm{pH}_{\mathrm{H} 20}$ of between 6.21-6.73. Soil texture also varies from sandy loam to loamy to sandy clay loam. In contrast to the other terrain units depicted along the catena, the riparian area's classification did not result in communities that could depict the different seasons of sampling. The vegetation classification resulted in five communities (Online Appendix 3). The vegetation of the riparian communities can be compared to communities 1 (Panicum maximum-Pupalia lappacea) and 2 (Themeda triandra-Flueggea virosa) from Theron et al.'s (2020) 2015 study:

1. Eragrostis cylindriflora-Urochloa mosambicensis Community

2. Themeda triandra-Panicum maximum Community

3. Eragrostis superba-Bothriochloa insculpta Community

4. Eragrostis rigidior-Urochloa mosambicensis Community

5. Bothriochloa radicans-Eragrostis superba Community

Riparian area community descriptions:

1. Eragrostis cylindriflora-Urochloa mosambicensis Community Diagnostic species: None

Constant species: Bare soil 67, Eragrostis cylindriflora 83, Panicum maximum 75, Urochloa mosambicensis 83

Dominant species: None

Eragrostis cylindriflora (Species Group G) and Urochloa mosambicensis (Species Group H) define this community. Species from Species Group A are mostly present in community 1 and absent or occur with low cover-abundance value in other communities in the riparian areas. This community represents sampling seasons 2, 4 and 5. It is notable that none of the relevés done during season 2 (just at the onset of the rainy season) is present in this community. Community 1 also share a lot of species from Species Group B with community 2:

2. Themeda triandra-Panicum maximum Community

Diagnostic species: None

Constant species: Cymbopogon caesius 68, Panicum maximum 95, Themeda triandra 95, Urochloa mosambicensis 74

Dominant species: None

Community 2 is defined by the presence of species from Species Group C, which are mostly restricted to this community although they occur with low cover-abundance values. Notable in this community is the strong presence of Themeda triandra (Species Group D) and Panicum maximum (Species Group $\mathrm{H}$ ), which were also present as diagnostic species defining the riparian areas in Theron et al. (2020). It seems as if Themeda triandra is mostly limited to this community with high cover-abundance values. However, Panicum maximum occurs throughout all the communities present in the riparian area throughout all the sampling seasons. This community is also 
mostly represented by sampling seasons 3 and 5 with some instances of sampling season 4 :

\section{Eragrostis superba-Bothriochloa insculpta Community}

Diagnostic species: None

Constant species: Bare soil 100, Bothriochloa insculpta 67, Eragrostis superba 100, Panicum maximum 67, Urochloa mosambicensis 67

Dominant species: None

Community 3 is the community with the lowest number of species in all the communities found in the riparian area, and there are no species that clearly distinguish this community from all the other communities in the riparian area. The cover abundance of species in this community is also low, and species do not occur in all the relevés found in this community. It is only the grass Eragrostis superba (Species Group H), known to grow in disturbed areas (Van Oudtshoorn 2018), that occurs in all three relevés that make up the community. Vegetation in this community mostly represents sampling seasons 2 and 5. The reason for the low number of species might be that the vegetation still needed to recover after the drought.

\section{Eragrostis rigidior-Urochloa mosambicensis Community}

Diagnostic species: None

Constant species: Bare soil 100, Eragrostis rigidior 77, Eragrostis superba 62, Urochloa mosambicensis 92

Dominant species: None

Vegetation in this community is dominated by species from Species Group E, which are mostly absent from the other communities in the riparian area. Furthermore, Urochloa mosambicensis (Species Group H) also occurs more frequently and with a higher cover abundance in this community. According to Van Oudtshoorn (2018), U. mosambicensis grows in disturbed or overgrazed and trampled areas. The high occurrence of this species in the riparian area might indicate that animals were seeking shade in order to evade the heat of the day during the drought (2015-2016). He further also indicated that Eragrostis rigidior is known to occur in disturbed soil. It is also important to note that most of the relevés present in this community represent sampling season 2, which was just after the 2015-2016 drought:

\section{Bothriochloa radicans-Eragrostis superba Community}

\section{Diagnostic species: None}

Constant species: Bare soil 62, Bothriochloa radicans 77, Dicoma tomentosa 62, Eragrostis superba 69

Dominant species: Bare soil 8

This is the only community that is solely represented by vegetation sampled during sampling season 4 . The vegetation is mostly dominated by the presence of species from Species Group F, which is mostly absent or occurs with low coverabundance values in other communities of the riparian area. The grasses Bothriochloa radicans and Eragrostis trichophora are known to occur in areas with additional moisture or where water collects (Van Oudtshoorn 2018). A possible explanation for this might be that after rains, water can remain close to the surface in the vicinity of the riparian area, which contributes to the additional moisture that is favourable for these grasses.

Although there is no distinction to be made between the sampling seasons in the riparian area of the study site, there are differences in the vegetation composition over the study period. When comparing the vegetation of the riparian area with communities 1 and 2 (Theron et al. 2020), it is clear that Panicum maximum, Urochloa mosambicenis and Themeda triandra remained an important part of the vegetation composition over all the different sampling seasons.

\section{Richness and diversity of plant communities}

From Figure 3a, it seems as if the species richness decreased at all the sites during the drought and subsequently increased more-or-less progressively through time as the communities recovered from the drought between 2015 and the onset of the current sampling period. However, pre- versus post-drought richness estimates are only significantly different for the sodic and riparian habitats (non-overlapping 95\% confidence intervals between groups); variance in estimates for the crest communities is high and overlaps with the pre-drought estimate. Interestingly, however, the recovery in species richness in

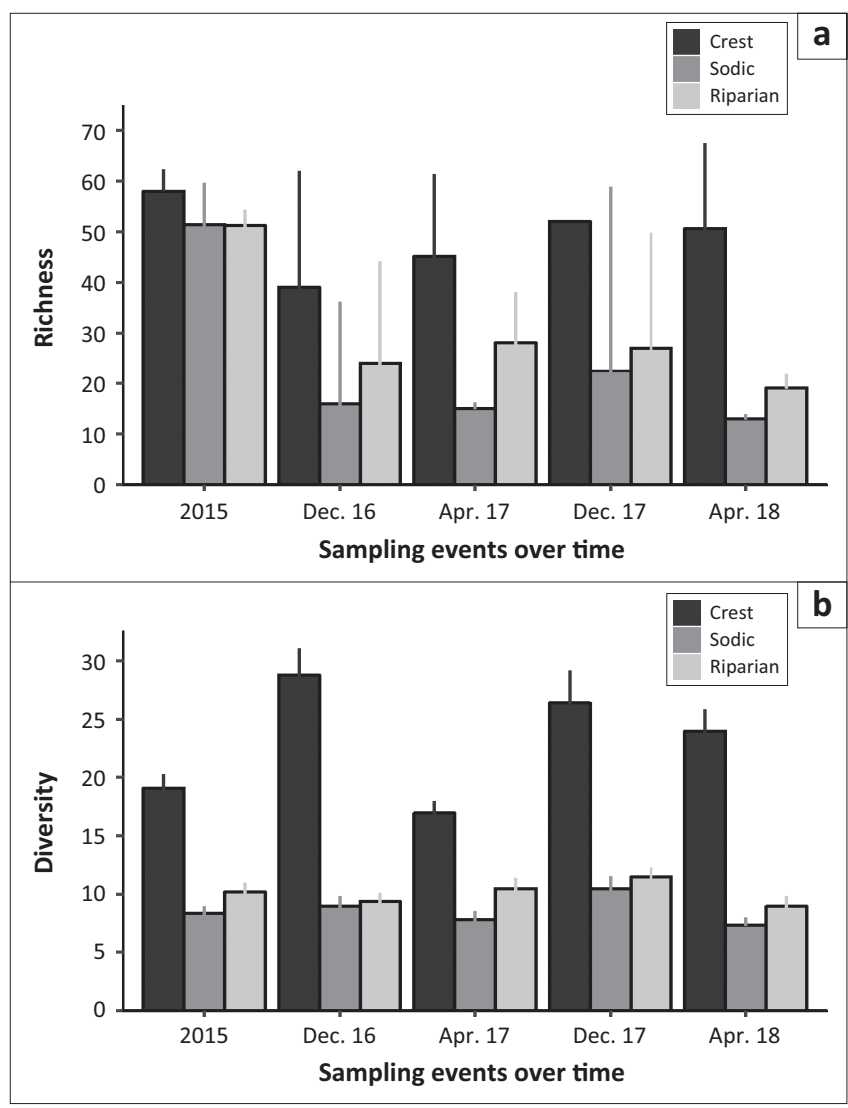

FIGURE 3: Bar chart representing the species richness (Chao estimate) and diversity (Shannon index) for the different sampling seasons at the different topographical units. The height of each column represents the mean, and the error bar represents the upper portion of the $95 \%$ confidence interval. 
sodic and riparian habitats appeared to slow or even reverse by the end of the study period (April 2018), although this could be because the final sample was taken in the dry season. Overall, species richness in crest habitats was greater than in both sodic and riparian habitats.

Figure $3 \mathrm{~b}$ represents the changes that took place in diversity over the different sampling seasons. In contrast to richness, species diversity did not differ between pre- and post-drought periods. However, a more cyclic seasonal shift is apparent, in that diversity was often highest in the wet seasons (December samples), compared with both dry season samples (April). The sodic and riparian habitats are an exception to this trend, because diversity in these areas was low in December 2016, perhaps because of a lag in recovery from the drought. As with species richness, diversity was also consistently greater in the crest, compared with the other two habitats.

While these indices of diversity provide some indication about changes in the studied communities, their overall function might be better represented in terms of changes in plant functional groups. Indeed, in all three habitats, the proportional representation of plant functional groups differed between 2015 and 2016, with climax and subclimax species being replaced by pioneers, perennials, annuals and - in some cases, especially in the sodic habitat - bare soil (Figure 4). By the end of the sampling period, however, the frequency distribution of functional groups at each habitat was qualitatively similar to pre-drought conditions.

\section{General discussion}

With this study, we aimed to determine how savanna plant communities along a catenal gradient changed over time following a severe drought. The catenal gradient studied could be divided into three plant communities - crest and midslope with the highest diversity; sodic site, and riparian areas. The crest and sodic sites further showed a definite change in species composition among the different sampling seasons. There was also an association between April sampling seasons for the crest as well as associations between the December and April sampling sites for the sodic site. Vegetation in the riparian section of the study revealed no clear distinction between different sampling seasons or any correlation between April and December. In a study by Scholes (1985), he investigated the drought of 1981-1983 and found that the grasses were more adversely affected by the drought than the trees. Although we excluded data for woody plants from this study, it is clear that vegetation changes took place in the ground layer (graminoids, forbs, herbs and geophytes), especially in the crest and sodic site communities (see Janecke 2020).

Previous studies have indicated that the physical and chemical properties of soils would affect grass mortality rates during drought conditions (Khomo \& Rogers 2005; Khomo et al. 2011; Scholes 1985). Specifically referring to the characteristics of the study site and its catenary properties, it

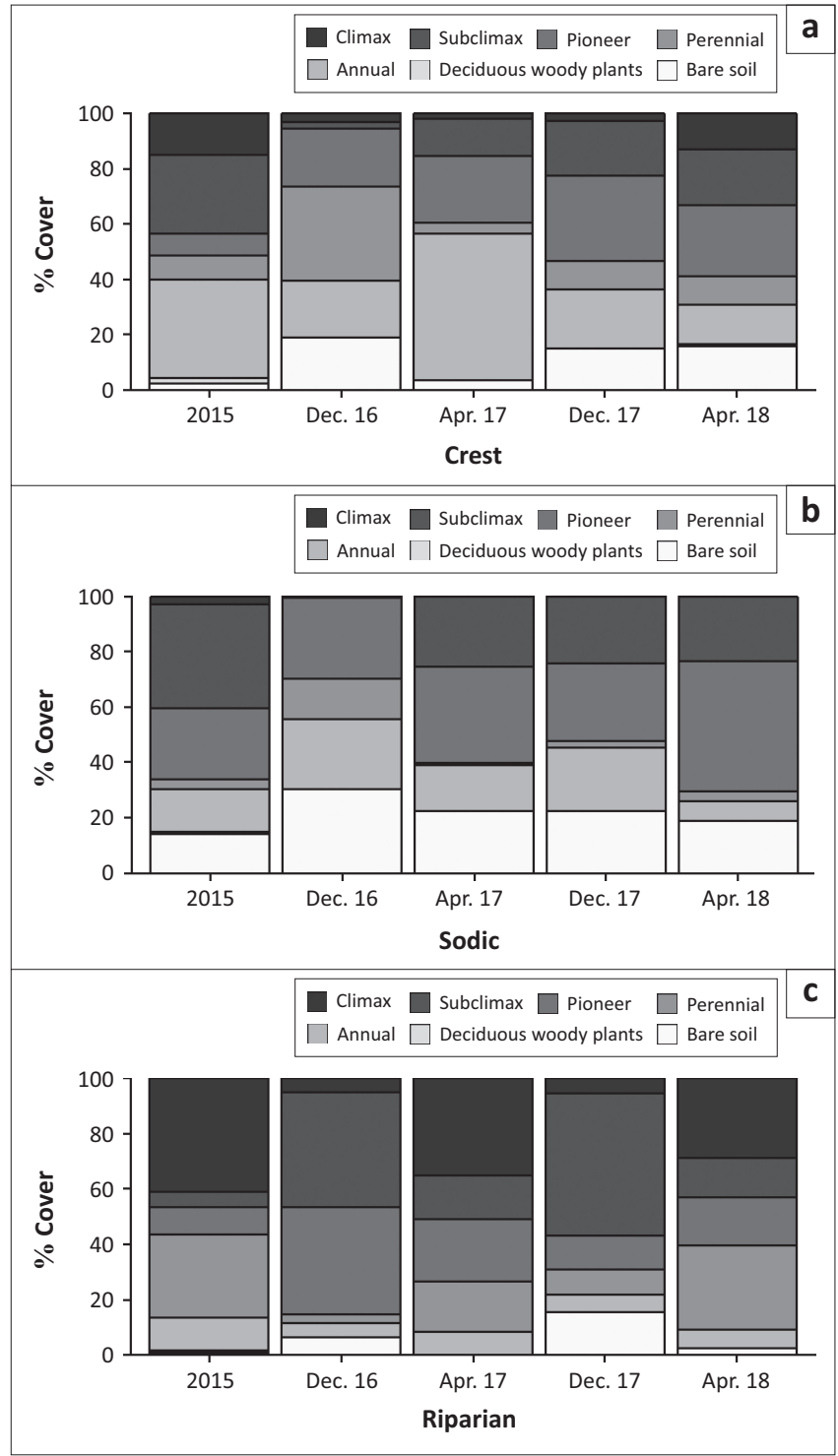

FIGURE 4: Graphs showing the different percentage covers of different growth forms ([a] crest, [b], sodic site and [c] riparian) during the different sampling seasons.

is expected that grasses inhabiting the sandy crest and valley bottoms would have a higher mortality rate than those inhabiting the clay-rich sodic sites and downslopes. The physical properties of sandy soils would compound the effects of droughts because they retain less water than do clay soils, and also through exasperating water infiltration and percolation of any available surface water. The effect of soil properties was shown to also affect this catena complex (Theron et al. 2020). This is also comparable to this study because most of the grass species dominating the climax community (sampling S1; 2015) returned to the vegetation composition of communities during sampling season 3 (April 2017). We furthermore found that richness and diversity declined and that recovery was not complete two years after the drought, especially in the sodic and riparian habitats, which have maintained a low level of species richness throughout the sampling period. These shifts coincided with changes in functional group representation following the drought. 


\section{Conclusion}

Definite changes in plant community composition were seen in the crest, midslope and sodic sites during the different sampling seasons. Shifts were also seen in terms of species composition at certain times of the year. This was not always clear in terms of richness and diversity of plant species. We would, however, be cautious to extrapolate these findings to all vegetation successions along a catena.

In the riparian area, no distinctions were clear between the different sampling seasons and no cyclic correspondence was observed between April and December. This phenomenon might be ascribed to water movement through the process of hydraulic lift from deeper soil layers which lessen the impact of drought on the vegetation.

We recommend that future studies following droughts should be done over more sampling seasons than reported here to better relate seasons to plant assemblages. Lastly, the recovery of the plant growth forms from 2015 to 2018 might be an indication of the resilience of the savanna ecosystem, in spite of the recovery not being complete.

\section{Acknowledgements}

The authors thank the South African National Parks for providing them with access to the research sites within Kruger National Park. A special thanks goes to the field rangers who accompanied them during the surveys. The authors also thank Louis Scott and Leslie Brown for suggestions on the writing of the manuscript.

\section{Competing interests}

The authors declare that they have no financial or personal relationships that may have inappropriately influenced them in writing this article.

\section{Authors' contributions}

E.J.T. and A.C.v.A. (partially) were responsible for the fieldwork and data collection during field surveys. A.C.v.A. and P.J.d.P. contributed towards the analysis and interpretation of the plant communities. D.C. contributed towards the analysis and interpretation of the statistical elements of the article. All authors contributed to the writing of the manuscript.

\section{Funding information}

The authors are grateful to the University of the Free State (UFS) Strategic Research Fund for partially funding this multidisciplinary research.

\section{Data availability}

Study data are available and may be provided, on request, by the corresponding author. Data from all research done within
Kruger National Park is placed within theSANParks repository (not for free, open access).

\section{Disclaimer}

The views and opinions expressed in this article are those of the authors and do not necessarily reflect the official policy or position of any affiliated agency of the authors.

\section{References}

Abbas, H.A., Bond, W.J. \& Midgley, J.J., 2019, 'The worst drought in 50 years in a South African savannah: Limited impact on vegetation', African Journal of Ecology 57(4), 1-10. https://doi.org/10.1111/aje.12640

Alard, G.F., 2009, 'A comparison of grass production and utilization in sodic and crest patches on a semi-arid granitic savanna catena in the southern Kruger National Park, South Africa', MSc thesis, Faculty of Science, University of the Witwatersrand.

Bond, W.J., Midgley, G.F. \& Woorward, F.I., 2003, 'What controls South African vegetation - Climate or fire?' South African Journal of Botany 69(1), 79-91. https://doi.org/10.1016/S0254-6299(15)30362-8

Bromilow, C., 2018, Problem plants and alien weeds of Southern Africa, 4th edn., Briza Publications, Pretoria.

Brown, L.R., Du Preez, P.J., Bezuidenhoudt, H., Bredenkamp, G.J, Mostert, T.H.C. \& Collins, N.B., 2013, 'Guidelines for phytosociological classifications and descriptions of vegetation in southern Africa', Koedoe 55(1), Art. \#1103, 10. https://doi.org/10.4102/koedoe.v55i1.1103

Buitenwerf, R., Swemmer, A.M. \& Peel, M.J.S., 2011, 'Long-term dynamics of herbaceous vegetation structure and composition in two African savanna reserves', Journal of Applied Ecology 48(1), 238-246. https://doi.org/10.1111/ j.1365-2664.2010.01895.x

Campbell, N.A., Reece, J.B, Urry, L.A., Cain, M.L., Wasserman, S.A., Minorsky, P.V., 2008, Biology, 8th edn., Pearson Benjamin Cummings, San Francisco, CA.

Fauchereau, N., Trzaska, S., Rouault, M. \& Richard, Y., 2003, 'Rainfall variability and changes in Southern Africa during the 20th century in the global warming context', Natural Hazards 29(2), 139-154. https://doi.org/10.1023/A:1023630924100

Furley, P., 2010, 'Tropical savannas: Biomass, plant ecology, and the role of fire and soil on vegetation', Progress in Physical Geography 34(4), 563-585. https://doi. org/10.1177/0309133310364934

Gommes, R. \& Petrassi, F., 1996, Rainfall variability and drought in sub-Saharan Africa, Food and Agriculture Organization of the United Nations, Rome.

Hsieh, T.C., Ma, K.H. \& Chao, A., 2016, 'iNext: An R package for rarefaction and extrapolation of species diversity (Hill numbers)', Methods in Ecology and Evolution 7(12), 1451-1456. https://doi.org/10.1111/2041-210X.12613

Hu, S. \& Fedorov, A.V., 2019, 'The extreme El Niño of 2015-2016: The role of westerly and easterly wind bursts, and preconditioning by the failed 2014 event', Climate Dynamics 48(1), 1-19. https://doi.org/10.1007/s00382-017-3531-2

Janecke, B.B., 2020, 'Vegetation structure and spatial heterogeneity in the Granite Supersite, Kruger National Park', Koedoe 62(2), a1591. https://doi.org/10.4102/ koedoe.v62i2.1591

Kent, M., 2012, Vegetation description and data analysis: A practical approach, 2nd edn., Wiley-Blackwell Publishers, West Sussex.

Kent, M. \& Coker, C., 1992, Vegetation description and analysis: A practical approach, Bellhaven Press, West Sussex.

Khomo, L.M., Hartshorn, A.S., Rogers, K.H. \& Chadwick, O.A., 2011, 'Impact of rainfall and topography on the distribution of clays and major cations in granitic catenas of Southern Africa', Catena 87(1), 119-128. https://doi.org/10.1016/j.catena.2011. 05.017

Khomo, L.M. \& Rogers, K.H., 2005, 'Proposed mechanism for the origin of sodic patches in Kruger National Park, South Africa', African Journal of Ecology 43(1), 29-34. https://doi.org/10.1111/j.1365-2028.2004.00532.x

Kruger, A.C., Makamo, L.B. \& Shongwe, S., 2002, 'An analysis of Skukuza climate data', Koedoe 45(1), 1-7. https://doi.org/10.4102/koedoe.v45i1.16

Mucina, L. \& Rutherford, M.C. (eds.), 2006, The vegetation of South Africa, Lesotho and Swaziland, Strelizia 19, South African National Biodiversity Institute, Pretoria.

R Core Team, 2015, computer software, $R$ : A language and environment for statistical computing, R Foundation for Statistical Computing, Vienna.

Roleček, J., Lubomír, T., David, Z., \& Milan, C., 2009, 'Modified TWINSPAN classification in which the hierarchy respects cluster heterogeneity', Journal of Vegetation Science 20(4), 596-602. https://doi.org/10.1111/j.1654-1103.2009.01062.x

Rouault, M. \& Richard, Y., 2003, 'Intensity and spatial extension of drought in South Africa at different time scales', Water SA 29(4), 489-500. https://doi.org/10.4314/ wsa.v29i4.5057

Scholes, R.J., 1985, 'Drought related grass, tree and herbivore mortality in a southern African savanna', in J.C. Tothill \& J.J. Mott (eds.), Ecology and management of the world's savannas, pp. 350-353, Australian Academy of Science, Washington, DC.

Scholes, R.J., 1997, 'Savanna', in R.M. Cowling, D.M. Richardson \& S.M. Pierce (eds.) Vegetation of Southern Africa, pp. 258-277, Cambridge University Press, Cambridge. 
Scholes, R.J., Bond, W.J. \& Eckhardt, H.C., 2003, 'Vegetation dynamics in the Kruger ecosystem', in J.T. Du Toit, K.H. Rogers \& H.C. Biggs (eds.), The Kruger experience: Ecology and management of Savanna heterogeneity, pp. 242-262, Island Press, London.

Schulze, R.E., 1997, 'Climate', in R.M. Cowling, D.M. Richardson \& S.M. Pierce (eds.) Vegetation of Southern Africa, pp. 21-42, Cambridge University Press, Cambridge.

Smit, I.P.J., Riddell, E.S., Cullum, C. \& Petersen, R., 2013, 'Kruger National Park research supersites: Establishing long-term research site for cross-disciplinary, multiscaled learning', Koedoe 55(1), Art. \#1107, 7, https://doi.org/10.4102/ koedoe.v55i1.1107

Staver, A.C., Wigley-Coetsee, C. \& Botha, J., 2018, 'Grazer movements exacerbate grass declines during drought in an African savanna', Journal of Ecology 107(1), 1482-1491.

Swemmer, A.M., Bond, W.J., Donaldson, J., Hempson, G.P., Malherbe, J. \& Smit, I.P.J., 2018, 'The ecology of drought - A workshop report', South African Journal of Science 114(9-10) Art.\#5098, 3. https://doi.org/10.17159/sajs.2018/5098

Swemmer, T., 2016, The Lowveld's worst drought in 33 years? Understanding the long term impacts, viewed 13 April 2017, from http://www.saeon.ac.za/newsletter/ archives/2016february/doc02.

Theron, E.J., Van Aardt, A.C. \& Du Preez, P.J., 2020, 'Vegetation distribution along a granite catena, southern Kruger National Park, South Africa', Koedoe 62(2), a1588. https://doi.org/10.4102/koedoe.v62i2.1588

Tichý, L. \& Holt, J., 2006, JUICE: A program for management, analysis and classification of ecological data, Vegetation Science Group, Brno.

Van der Maarel, E., 2007, 'Transformation of cover-abundance values for appropriate numerical treatment - Alternatives to the proposals by Podani', Journal of Vegetation Science 18(5), 767-770. https://doi.org/10.1111/j.1654-1103.2007. tb02592.x
Van der Maarel, E. \& Franklin, J., 2013, Vegetation ecology, 2nd edn., John Wiley \& Sons, Chichester.

Van Oudtshoorn, F., 2018, Guide to grasses of southern Africa, Briza Publications, Pretoria.

Van Wyk, B. \& Malan, S., 1998, Field guide to the wild flowers of the Highveld, Struik Nature, Cape Town.

Van Zijl, G. \& Le Roux, P., 2014, 'Creating a conceptual hydrological soil response map for the Stevenson Hamilton Research Supersite, Kruger National Park, South Africa', Water SA 40(2), 331-336.

Venter, F.J., 1990, 'A classification of land for management planning in the Kruger National Park', PhD thesis, University of South Africa, Pretoria.

Venter, F.J., Scholes, R.J. \& Eckhardt, H.C., 2003, 'The abiotic template and its associated vegetation pattern', in J.T. Du Toit, K.H. Rogers \& H.C. Biggs (eds.), The Kruger experience: Ecology and management of savanna heterogeneity, pp. 83-129, Island Press, London.

Vetter, S., 2009, 'Drought, change and resilience in South Africa's arid and semi-arid rangelands', South African Journal of Science 105(1-2), 29-33. https://doi. org/10.4102/sajs.v105i1/2.35

Walker, B.H., Emslie, R.H., Owen-Smith, R.N. \& Scholes, R.J., 1987, 'To cull or not to cull: Lessons from a southern African drought', Journal of Applied Ecology 24(2), 381-401. https://doi.org/10.2307/2403882

Zambatis, N., 2006, Average monthly and seasonal temperatures $\left({ }^{\circ} \mathrm{C}\right)$ of the Kruger National Park, Scientific Services, Kruger National Park, Cape Town.

Zambatis, N. \& Biggs, H.C., 1995, 'Rainfall and temperatures during the 1991/92 drought in the Kruger National Park', Koedoe 38(1), 1-16. https://doi.org/10.4102/ koedoe.v38i1.301 